\title{
Stabilization of guava nectar with hydrocolloids and pectinases
}

\author{
Fernanda Döring Krumreich ${ }^{1 *}$, Ana Paula Antunes Corrêa ${ }^{2}$, Jair Costa Nachtigal' ${ }^{2}$, Gerson Lübke Buss ${ }^{3}$, \\ Josiane Kuhn Rutz ${ }^{1}$, Michele Maciel Crizel-Cardozo ${ }^{1}$, Cristina Jansen ${ }^{1}$ and Rui Carlos Zambiazi ${ }^{1}$ \\ 'Post Graduate Program of Food Science and Technology, Faculty of Agronomy Eliseu Maciel, \\ Universidade Federal de Pelotas - UFPel, Pelotas, RS, Brazil \\ ${ }^{2}$ Empresa Brasileira de Pesquisa Agropecuária - Embrapa, Pelotas, RS, Brazil \\ ${ }^{3}$ Post Graduate Program Agronomy/Soil, Faculty of Agronomy Eliseu Maciel, Universidade Federal \\ de Pelotas - UFPel, Pelotas, RS, Brazil \\ *nandaalimentos@gmail.com
}

\begin{abstract}
The aim of this study was to stabilize guava nectar using hydrocolloids and/or enzymes, and evaluate the stability and the bioactive compounds content during storage. In general, there was a decrease in $\mathrm{pH}$ and an increase in titratable acidity and soluble solids of the nectars. During storage, it was observed that nectars with pectinase showed decrease in $\mathrm{pH}$, increase in titratable acidity and soluble solids, and also less phase separation, standing out among them the nectar with enzyme and guar gum. The nectar formulated with xanthan showed the highest antioxidant capacity. All nectars showed slight decrease in the carotenoid content and high losses of vitamin $\mathrm{C}$ during the storage period.
\end{abstract}

Keywords: bioactives, hydrocolloids, nectar, pectinases.

\section{Introduction}

Guava belongs to the Myrtaceae family, genus Psidium, which comprises up to 130 species of which only guava Psidium guajava L. has economic importance ${ }^{[1]}$. Guava fruits ripen quickly and have a shelf life up to 8 days, thus the processing technology can ensure the excess of production and exploitation in off-season periods ${ }^{[2]}$. Although the fruit is used for production of juices, pulps and nectars, as well as jams, jellies, fruit preserves, purees, syrups, wines, among others ${ }^{[3]}$. According to ABIR ${ }^{[4]}$, the demand for nectars is growing in Brazil. The Ministry of Agriculture and Supply, which is the regulatory agency of the processing industries of juices and fruit nectars and identity standards ${ }^{[5]}$ defines guava nectar as a non-fermented beverage produced by dissolution of guava pulp (Psidium guajava L.) and sugars in drinking water, intended for direct consumption, with or without addition of acids. The attributes color and turbidity are decisive for the acceptance of juices and nectars, which should not present sedimentation or phase separation, even with preservation of the nutritional value and taste ${ }^{[6]}$. Phase separation is associated with chemical interactions, density between the disperse phase and dispersant, particle size and viscosity of the disperse phase.

Several hydrocolloids have been widely used in the food industry, aimed to provide the gel structure, increase viscosity, act as encapsulating agent in formation of films, control crystallization, inhibit syneresis, and increase the physical stability of the products ${ }^{[7]}$. These hydrophilic polymers can directly influence the properties of foods, such as appearance and texture. Xanthan and chitosan stand out among the widely used hydrocolloids.
The attributes color and turbidity are decisive for the acceptance of juices and nectars, which should not present sedimentation or phase separation, even with preservation of the nutritional value and taste ${ }^{[6]}$. Phase separation is associated with chemical interactions, density between the disperse phase and dispersant, particle size and viscosity of the disperse phase. In this context, the aim of this study was to stabilize the guava nectar (Psidium guajava L.) using hydrocolloids and pectinase and evaluate the stability of the bioactive compounds during storage of the nectars.

\section{Materials and Methods}

\subsection{Material}

About $20 \mathrm{~kg}$ of Paluma guavas were obtained from a farm in the municipality of Pelotas, RS, Brazil during the 2013-2014 harvest. Xanthan, guar gum, pectinase enzyme (Sigma-Aldrich) and pregelatinized rice flour, were used as stabilizers. The pectinase enzyme is composed mainly by pectin lyase, polygalacturonase and pectinmethylesterase and small amounts of cellulases and hemicellulases. The other reagents used in spectrophotometric analyses were of analytical grade.

\subsection{Nectar processing}

Guavas were selected and sanitized in chlorinated water (500 ppm active chlorine), and then the pulp was removed in a machine equipped with $0.8 \mathrm{~mm}$ mesh wire. The pulp was packed in polyethylene bags with a capacity of $1 \mathrm{~kg}$ and stored at $-18^{\circ} \mathrm{C}$ until production of nectars. For other 
formulations, stabilizers (xanthan, guar gum, pregelatinized rice flour) and/or pectinase enzyme were added according to Sousa et al. ${ }^{[8]}$ and Rodrigues methodology ${ }^{[9]}$ (Table 1).

The gums were initially dispersed in the sugar and slowly added into the guava pulp to prevent lump formation. The homogenization was carried out in an industrial blender, followed by a $90^{\circ} \mathrm{C} / 10 \mathrm{~min}$ heat treatment. After this period the hot filling $\left(85^{\circ} \mathrm{C}\right)$ was carried out in previously sterilized $150 \mathrm{~mL}$ glass bottles. The manual closure was performed with metal lids, and was cooled by immersion with water at $45^{\circ} \mathrm{C}$ and $25^{\circ} \mathrm{C}$ respectively. The bottles were kept at room temperature $\left(22^{\circ} \mathrm{C} \pm 3.6^{\circ} \mathrm{C}\right)$ for 180 days period.

\subsection{Physicochemical analysis}

Analyses of guava nectars were performed soon after processing and at 45 day intervals during 180 days. All determinations were performed in triplicate, as follows:

\subsection{1 $\mathrm{pH}$}

Determined by potentiometric method ( $\mathrm{pHmeter}$ Digimed DM 20), using pH 4.0 and 7.0 buffer solutions.

\subsubsection{Titratable acidity}

Determined by titration the sample with $0.1 \mathrm{~N}$ sodium hydroxide $(\mathrm{NaOH})$ to $\mathrm{pH} 8.1$. The results were expressed in $\mathrm{mg}$ citric acid per $100 \mathrm{~g}$ sample (wet basis) ${ }^{[10]}$.

\subsubsection{Total soluble solids}

Determined by refractive index, using digital refractometer Atago Palette PR-32 $\alpha$.

\subsubsection{Color}

Measured according to the C.I.E. L* $\mathrm{a}^{*} \mathrm{~b}^{*}$ system, in colorimeter Minolta (CR-300), with illuminant D 65, $8 \mathrm{~mm}$-illumination area, and $\mathrm{L} *$ values (brightness) ranging from black (0) to white (100); a* values from green (-a) to red $(+a)$, and $b^{*}$ values ranging from blue $(-b)$ to yellow $(+b)$.

\subsubsection{Phenolic compounds}

For quantification of total phenolics was used the method described by Swain and Hillis ${ }^{[1]}$, with few modifications. Absorbance readings were performed in a spectrophotometer (JENWAY, $6700 \mathrm{UV} / \mathrm{Vis}$ ) at $725 \mathrm{~nm}$. A gallic acid standard curve was used for quantification of the phenolic compounds,

Table 1. Amount of gums and enzymes in the nectars of guava.

\begin{tabular}{lc}
\hline \multicolumn{1}{c}{ Formulations* } & Amount \\
\hline (T1) Control** & - \\
(T2) Xanthan & $0.1 \%$ \\
(T3) Guar gum & $0.1 \%$ \\
(T4) Pregelatinized rice flour & $0.1 \%$ \\
(T5) Enzyme & $1,400 \mathrm{ppm}$ \\
(T6) Enzyme + Xanthan & $1,400 \mathrm{ppm}+0.1 \%$ \\
(T7) Enzyme + Guar gum & $1,400 \mathrm{ppm}+0.1 \%$ \\
(T8) Enzyme + Pregelatinized rice flour & $1,400 \mathrm{ppm}+0.1 \%$ \\
\hline
\end{tabular}

*The formulations of the nectars were carried out in accordance with Resolution No.12 of 04 September 2003, Art 1 Annex II - Identity Standards and Quality Nectar ${ }^{[5]}$; **The base formulation (control) of the nectars consists of $55 \%$ water, $35 \%$ guava pulp and $10 \%$ sugar (sucrose) and the results were expressed as mg of gallic acid equivalents per $100 \mathrm{~g}$ sample (wet basis).

\subsubsection{Carotenoids}

Total carotenoids were determined according to AOAC ${ }^{[12]}$ method. Absorbance readings were performed in a spectrophotometer (JENWAY, $6700 \mathrm{UV} / \mathrm{Vis}$ ) at $470 \mathrm{~nm}$. A lycopene standard curve was used for quantification of total carotenoids, and the results were expressed as mg of lycopene equivalents per $100 \mathrm{~g}$ sample (wet basis).

\subsubsection{Antioxidant capacity}

The antioxidant capacity was determined by the ability of the compounds to sequester the radical DPPH (2,2- difenil-1-picrilhidrazila), second method described by Brand-Williams et al. ${ }^{[13]}$. Absorbance readings were performed in a spectrophotometer (JENWAY, $6700 \mathrm{UV} / \mathrm{Vis}$ ) at $517 \mathrm{~nm}$ after 24 hours of reaction, and the results were calculated according to Equation 1, expressed as percentage inhibition of DPPH radical.

$\%$ Inhibition $=\frac{\text { absorbance of control }- \text { absorbance of sample }}{\text { absorbance of control }} \times 100$

\subsubsection{L-ascorbic acid}

Quantified using the titrimetric method of Lorenz-Steves ${ }^{[14]}$, based on the reducing action of ascorbic acid, using standard iodine and sodium thiosulfate solution and starch as indicator. The results were calculated according to Equation 2, and expressed as mg of L-ascorbic acid per $100 \mathrm{~g}$ sample (wet basis).

$m g$ ascorbic acid $100 m L^{-1}$ of juice $(X)=[Y \times 0,88 \mathrm{mg}] / \mathrm{mL}$

Where: $\mathrm{Y}=($ total volume of iodine solution $\mathrm{X}$ conversion factor) - (volume of thiosulfate solution $\mathrm{x}$ conversion factor) Each $\mathrm{mL}$ of $0.01 \mathrm{~N}$ iodine corresponds to $0.88 \mathrm{mg}$ of ascorbic acid.

\subsubsection{Sedimentation}

The clarified phase of nectars was analyzed twice a week for 90 days, which corresponds to the stabilization period, and the results were expressed as percentage of stabilized phase (not clarified).

\subsubsection{Statistical analysis}

The results were expressed as mean and standard deviations concerning the determinations in triplicate. Data were submitted to Tukey's and Dunnett test, with 5\% significance level, using the SAS statistical software v8.

\section{Results and Discussion}

The $\mathrm{pH}$ of the nectar formulations containing xanthan (T2), guar gum (T3) and rice flour (T4) did not differ significantly from the control (T1) formulation (4.17 \pm 0.01$)$. Lower $\mathrm{pH}$ values were observed for all formulations containing the enzyme, including the formulations with pectinase (T5), pectinase and xanthan (T6), pectinase and guar gum (T7), and pectinase and rice flour (T8). Godoy ${ }^{[15]}$, studied hydrocolloids in guava nectar and found an increase 
in $\mathrm{pH}$ value in the control (guava nectar without addition of stabilizer) when xanthan gum was used at various concentrations $(0.07,0.12$ and $0.17 \%)$. Souza ${ }^{[16]}$ also observed an increase in $\mathrm{pH}$ value when xanthan and guar gum were used in peach nectar, when compared to the control. The $\mathrm{pH}$ determination is of great importance, since it is a limiting factor for the growth of pathogenic and spoilage bacteria; in addition it defines the heat treatment to be applied, and favors the stability of ascorbic acid, since this vitamin has greater stability at acidic $\mathrm{pH}^{[14]}$.

During storage (Figure 1A), a significant increase in $\mathrm{pH}$ value was observed for all nectar formulations, except for the nectar containing xanthan gum (T2) and guar gum (T3) at 180 days of storage. These results corroborate the results of several authors, including Silva et al. ${ }^{[17]}$, studying the stability of guava juice packed either in glass bottles or carton, and storing for 250 days at room temperature; Mattietto et al. ${ }^{[18]}$ study with a blend of cajá and umbu nectar packed in glass bottles for 90 days of storage; Leitã $0^{[19]}$, study with blackberry nectar packed in glass or polypropylene packages and stored either at room temperature or refrigeration; and Carvalho et al. ${ }^{[20]}$, studying a blended beverage consisting of cashew apple juice and coconut water containing caffeine. According to Silva ${ }^{[21]}$, the increase in $\mathrm{pH}$ value during storage may be due to the degradation of ascorbic acid, with respective reduction of free hydrogen ions in the product, which corroborates the findings of this study, once a significant decrease in vitamin $\mathrm{C}$ content was observed during storage.

The determination of acidity is another important physicochemical parameter for processing nectars, since it ensures a more pleasant taste and a more vivid color to the products. After processing, all nectars containing the enzyme pectinase (T5, T6, T7 and T8) showed higher total acidity and lower $\mathrm{pH}$ values when compared to the control. Essa ${ }^{[22]}$, studied the effects of the addition of an enzyme preparation on plum, banana, and guava juices, and found an average titratable acidity of $0.31 \%$ citric acid, which is very close to the value found in our study for the nectars containing the enzyme $(0.27 \%$ citric acid). However, after the enzymatic treatment, the author found a considerable decrease in viscosity of banana juice. Byaruagaba-Bazirake et al. ${ }^{[23]}$ found no changes in acidity of the pulp after enzymatic treatment. The decrease in $\mathrm{pH}$ and increase in acidity of nectar formulations containing the enzyme is expected, since the enzymatic treatment increases the galacturonic acid content in the medium, which is present as pectin chains in the cell walls. An increase in acidity was also observed by Demir et al. ${ }^{[24]}$ with no changes in $\mathrm{pH}$, probably due to the compounds from carrot juice that may act as a buffer. Vandresen $^{[25]}$, evaluated enzymatically treated and pasteurized carrot juice, and also found a decrease in $\mathrm{pH}$ and an increase in acidity of the pasteurized samples.

In the present study, the titratable acidity remained stable for all formulations during 180 days of storage (Figure 1B), which did not decrease with the increase in $\mathrm{pH}$, particularly at 135 days of storage. There was a slight decrease in acidity of some formulations during the storage time, which was more evident in the formulation containing pectinase and xanthan gum (T6). Pinheiro ${ }^{[26]}$, studied blended cashew apple nectar stored for 30 days, and observed small changes in acidity of nectar packed either in polyethylene terephthalate or glass packages. Similar results were observed by Corrêa ${ }^{[27]}$, who evaluated guava nectar stored at refrigerated $\left(5 \pm 2{ }^{\circ} \mathrm{C}\right)$ and room temperature $\left(25 \pm 5^{\circ} \mathrm{C}\right)$ for 120 days, and also by Beisman ${ }^{[28]}$ during storage of mango nectar formulations.

The soluble solids content of the guava nectar formulations were significantly higher $(14.03 \pm 0.12)$, when compared to the control, except for the formulation with guar gum (T3). The increase in soluble solids was expected, due to the addition of solids in all formulations. The formulation with the pectinase enzyme and rice flour (T8) was the one with the highest amount of soluble solids (16.10 $\left.{ }^{\circ} \mathrm{Brix}\right)$, and the highest values were observed in the formulations containing pectinases enzymes (T5, T6, T7, T8). These results are probably due to the action of the pectinolytic enzymes that hydrolyze the $\alpha(1 \rightarrow 4)$ glycosidic bonds, which increases the soluble solids content in solution. According to Sreenath et al. ${ }^{[29]}$ the enzyme improves the quality of the juice by providing a greater extraction of soluble solids. This effect was also found by Brasil et al. ${ }^{[30]}$ in extraction and bleaching of guava juice, using $600 \mathrm{ppm}$ of enzyme at $45^{\circ} \mathrm{C}$ for 120 minutes, and by Vandresen ${ }^{[25]}$ evaluating enzymatically treated and pasteurized carrot juice.

During storage (Figure 1C), the soluble solids content remained constant for all nectar formulations, which corroborates with the study of Nisida et al. ${ }^{[31]}$ who investigated orange juice packed in aseptic packaging and stored at different temperatures $\left(2^{\circ} \mathrm{C}, 12^{\circ} \mathrm{C}\right.$ and $\left.35^{\circ} \mathrm{C}\right)$, and observed that the concentration of soluble solids remained constant during storage at the three temperatures studied. According to the Ministry of Agriculture, Livestock and Supply, the minimum soluble solids content for guava nectars is $10^{\circ} \mathrm{Brix}^{[5]}$; thus all nectar formulations of this study were within the
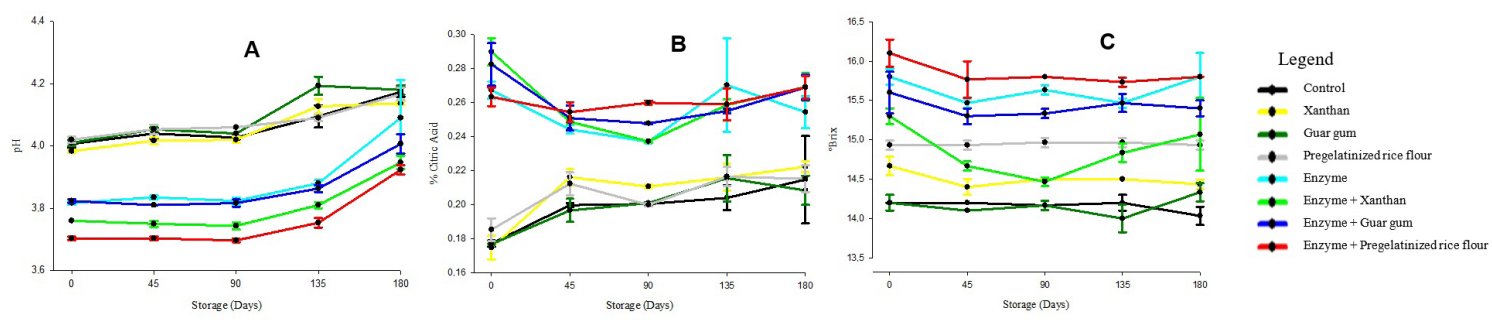

Figure 1. Effect of addition of enzymes and the $\mathrm{pH}$ hydrocolloid (A), titratable acidity (B) and total soluble solids (C) nectars guava during storage. 
minimum limit defined by the legislation until the end of the storage period.

The color parameters $\left(L^{*}, a^{*}\right.$ and $\left.b^{*}\right)$ of all nectar formulations remained very close to the control during the storage periods. However, a significant decrease in $\mathrm{L}^{*}$ values was observed for the treatments with xanthan (T2), pectinase (T5), pectinase and xanthan (T6), pectinase and guar gum (T7), and pectinase and rice flour (T8) at the beginning (day 0 ) and at the end of storage (day 180). When nectar was analyzed individually in relation to the storage time (Figure 2A), $L^{*}$ values significantly increased after 90 days of storage, with subsequent reduction. Sharon et al. ${ }^{[32]}$ studied passion fruit juice, and also found a significant increase in brightness values for 120 days of storage. According to the authors, Maillard reactions may occur, with non-enzymatic browning or even polymerization of phenolic compounds. Tribst $^{[33]}$ evaluated mango nectar, and also found higher $\mathrm{L}^{*}$ values due to the heat treatment to which the product was subjected. Arruda ${ }^{[34]}$, studied the stability of mango nectar packed in polyethylene terephthalate bottles, aluminum cans and cartons, and observed a decrease in $\mathrm{L}^{*}$ values during storage due to the oxidation reactions and vitamin $\mathrm{C}$ losses.

Both the $\mathrm{a}^{*}$ and the $\mathrm{b}^{*}$ values show a trend to increasing values for all guava nectars during storage, probably due to the carotenoids content in nectars, since the higher the $\mathrm{a}^{*}$ and $b^{*}$ values the closer they are to red and yellow, respectively. Different nectar formulations showed color values similar to the control. An increase in a* values (Figure 2B) was also observed by Sharon et al. ${ }^{[32]}$ in passion fruit juice during storage. The increase in red color may have been influenced by heating, which causes loss of some components such as carotenoids, sugars, and amino acids, leading to the formation of colored products from the Maillard reaction.

Higher $b^{*}$ values were observed only in some formulations at 90 and 135 days of storage (Figure 2C), when compared to the control. During the 180 day storage, several oscillations were observed in this parameter, with a more significant decrease at 45 days, with no significant differences between the formulations and the control at the end of the study period. The $b^{*}$ values ranged from 1.24 to 4.98 , with small increase in yellow color during storage, probably due to the heat treatment applied to nectars, which caused an increase in yellowness. Beisman ${ }^{[28]}$ evaluated the darkening of guava nectar and observed color changes during storage at room temperature, probably due to the rapid degradation of ascorbic acid in the product. This color coordinate plays an important role in guava nectars, since it is directly related to the carotenoid content in the product, which did not change during storage in all samples analyzed in the present study, thus reflecting in $b^{*}$ values.

Although the carotenoid levels ranged during storage (Figure 3A); lower levels were observed in both the formulations containing xanthan gum (T2) and formulations containing pectinase (T5, T6, T7, T8) at the end of storage, with a small increase in the other samples. Lin \& Chen $^{[35]}$, studied the stability of carotenoids in tomato juice heated at $121^{\circ} \mathrm{C}$ for 40 seconds and stored in the absence and presence of light $(10 \mathrm{~W})$ at $4{ }^{\circ} \mathrm{C}, 25^{\circ} \mathrm{C}$ and $35^{\circ} \mathrm{C}$ for 12 weeks, and observed losses of $80.1 \% ; 83.5 \%$ and $92.1 \%$, respectively, for the samples stored in the absence of light, and $87.4 \%$; $84.9 \%$ and $88.3 \%$, respectively, for the samples stored in the presence of light after 90 days of storage. Fernandes et al. ${ }^{[36]}$ investigated hot-packed guava juice stored for 30 days at $28{ }^{\circ} \mathrm{C}$, and found a decrease in lycopene content from $1.51 \mathrm{mg} .100 \mathrm{~g}^{-1}$ to $1.22 \mathrm{mg} .100 \mathrm{~g}^{-1}$. Silva et al. ${ }^{[17]}$ also studied guava juice, and found carotenoids content of approximately $1.0 \mathrm{mg}$ lycopene $100 \mathrm{~g}^{-1}$, which did not differ within 250 days of storage. The contents reported by those authors are lower than to those found for the guava nectars in our study. Overall, the samples containing pectinases exhibited higher carotenoids levels when compared to the other samples, both after processing as the end of the storage period.

Phenolic compounds belong to a group of compounds with variable stability, due to their different structures, being directly affected by temperature, light, contact with oxygen, $\mathrm{pH}$, among others. All formulations had very similar content of phenolic compounds after processing in our study (Figure 3B). During storage, a progressive decrease in phenolics was observed for all formulations, except after 90 days of storage. It is observed that unlike the carotenoid content, no differences were observed between the formulations containing or not the enzymes. Paludo and Krüger ${ }^{[37]}$ extracted juice with and without addition of the enzyme pectinase, and also found no significant difference in the phenolic compounds content. Valdés et al. ${ }^{[38]}$ studied guava juice packed in glass packages, and found phenolic compounds content of $26.3 \mathrm{mg}$ of gallic acid equivalents. $100 \mathrm{~g}^{-1}$, which is lower than the content found in our study. Other guava derived products also presented a decrease in phenolic compounds during storage. Singh \& $\mathrm{Pal}^{[39]}$ analyzed guava stored under controlled atmosphere for 30 days at $8{ }^{\circ} \mathrm{C}$, and reported a reduction in phenolic compounds from $224.26 \mathrm{mg}$ to $190.56 \mathrm{mg}$ gallic acid equivalents. $100 \mathrm{~g}^{-1}$. Silva et al. ${ }^{[17]}$ found a reduction from $128.33 \mathrm{mg}$ to $94.98 \mathrm{mg}$ gallic acid equivalents. $100 \mathrm{~g}^{-1}$ in hot
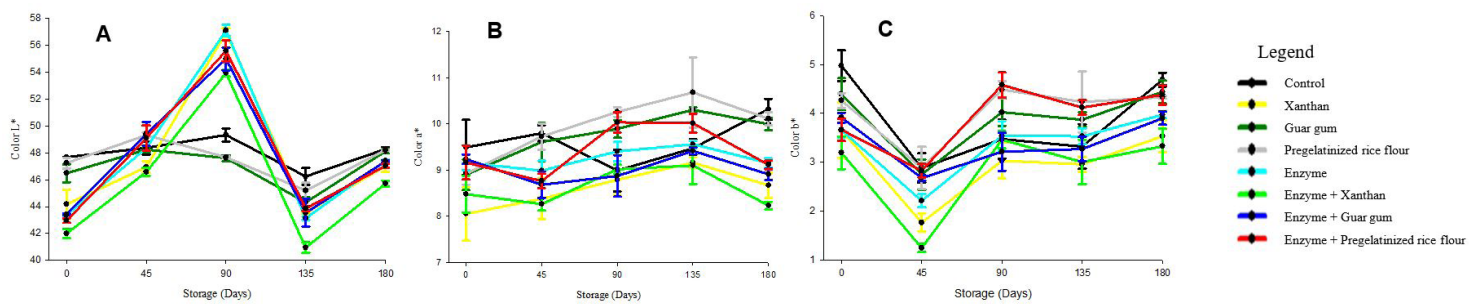

Figure 2. Influence of the addition of hydrocolloids and enzymes in color parameters $\mathrm{L}^{*}(\mathrm{~A}), \mathrm{a}^{*}(\mathrm{~B})$ and $\mathrm{b}^{*}(\mathrm{C})$ of guava nectars during storage. 

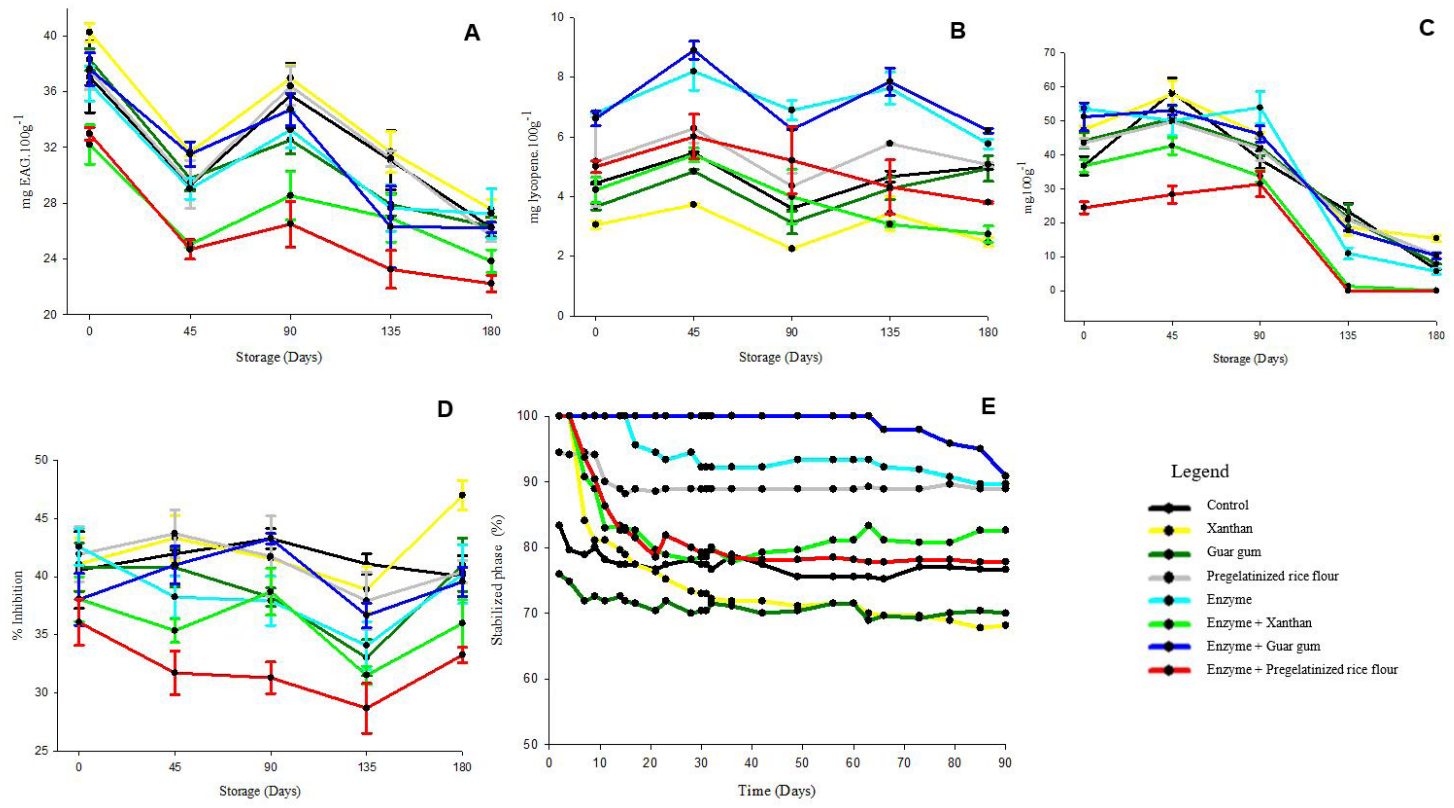

Figure 3. Influence of the addition of hydrocolloids and enzymes in the carotenoid (A), phenolic compounds (B), L-ascorbic acid (C), antioxidant (D) and sediment (E) nectars guava during storage.

packed guava juice, and from $96.55 \mathrm{mg}$ to $74.38 \mathrm{mg}$ gallic acid equivalents. $100 \mathrm{~g}^{-1}$ in juice subjected to aseptic processing, from 50 to 250 days of storage at room temperature. In the present study, pasteurization was used in the preparation of guava nectars, which may be associated with the degradation rate of phenolic compounds during storage.

All guava nectars exhibited similar ascorbic acid content throughout storage when compared to the control, except the formulation containing pectinase and rice flour (T8), which showed a lower ascorbic acid content (Figure 3C). The vitamin $\mathrm{C}$ decreased in all guava nectars during storage, and no vitamin $\mathrm{C}$ content was found in both the formulations containing pectinase and xanthan gum (T6), and formulation with pectinase and rice flour (T8) after 180 days. Although greater protection on vitamin $\mathrm{C}$ was observed in nectars containing gums, the degradation of this vitamin was accelerated in nectars with pectinase. The greatest decrease in vitamin $\mathrm{C}$ content was observed from 135 days of storage for all formulations. Leitão ${ }^{[19]}$ found $82.32 \%$ degradation of this vitamin in blackberry nectar stored at refrigeration temperature $\left(4 \pm 2{ }^{\circ} \mathrm{C}\right)$, and $100 \%$ degradation when stored at room temperature for 90 days, evidencing lower degradation of vitamin $\mathrm{C}$ at low temperatures. Among all formulations, the nectar with xanthan gum (T2) retained the vitamin C content $\left(15.36 \mathrm{mg} .100 \mathrm{~g}^{-1}\right)$ within the parameters of the legislation, $14 \mathrm{mg} \cdot 100 \mathrm{~g}^{-1[5]}$. Despite guava is a rich source in this vitamin, it is easily degraded during processing and/or storage due to its instability. Quinteros ${ }^{[40]}$, studied the stability of acerola and carrot nectar, and found a more accelerated loss in the first 90 days of storage, decreasing after this period; unlike the results of the present study, in which vitamin $C$ remained stable at the beginning of storage, with significant degradation at the end of 135 days. A reduction in vitamin $\mathrm{C}$ was also reported by Brito et al. ${ }^{[41]}$ in passion fruit nectar containing coconut water stored at room temperature $\left(25^{\circ} \mathrm{C}\right)$, with a loss of $77.87 \%$ at the end of 90 days. Similar results were observed by Sousa ${ }^{[8]}$, which reported $38 \%$ loss of vitamin $\mathrm{C}$ in the nectar containing Ginkgo biloba, Panax Ginseng extracts during 180 days of storage at room temperature $\left(25^{\circ} \mathrm{C}\right)$. Oliva et al..$^{[42]}$ investigated the stability of vitamin $\mathrm{C}$ in acerola fruit nectar, and reported losses from $28 \%$ to $30 \%$ when stored at room temperature at the end of 150 days. The reduction in vitamin $\mathrm{C}$ content of nectars during storage can be due to oxidation reactions caused by oxygen inside the package and/or dissolved in the beverage, since nectar was not subjected to deaeration process. The storage temperature and the incidence of light in transparent glass packaging may also have contributed to the reduction of vitamin $\mathrm{C}$ levels ${ }^{[43]}$. According to Fellows ${ }^{[4]}$, pasteurization also causes changes in the nutritional value of food, especially in relation to vitamin $\mathrm{C}$ in fruit juices despite being a relatively mild heat treatment. There is a vast literature on the chemical oxidation and/or thermal degradation of vitamin $\mathrm{C}$ as a result of bleaching, baking, pasteurization, sterilization, dehydration and freezing ${ }^{[45]}$. Besides these processing conditions, other factors such as type of packaging, presence of $\mathrm{O}_{2}$, time and temperature of storage, and incidence of light ${ }^{[46]}$ can also contribute to the degradation of vitamin C. Despite significant losses of ascorbic acid were observed in guava nectars up to 180 days of storage, some formulations showed values above the Recommended Daily Intake (RDI) for adults, which is $45 \mathrm{mg}$ daily, until 90 days of storage ${ }^{[47]}$.

Significant differences were observed for the antioxidant activity of guava nectar formulations when compared to the control from 90 to 135 days of storage (Figure 3D). During storage, the different formulations showed variable activity, and all samples containing pectinase (T5, T6, T8), showed a tendency to lower antioxidant activity, except the formulations containing pectinase and guar gum (T7). The decrease of 
the antioxidant activity is due to the loss of carotenoids, phenolic compounds, and vitamin $\mathrm{C}$ during storage, which was more intense in these formulations when compared to the other formulations, especially in the formulations with pectinase and xanthan gum (T6), and pectinase and flour rice (T8), in which vitamin $\mathrm{C}$ was not detected at the end of the storage period. The formulation containing only xanthan gum (T2) showed increased antioxidant capacity during storage, demonstrating its stabilizing potential, not only in the product's appearance but also the content of bioactive compounds. Leitão ${ }^{[19]}$, evaluated the stability of blackberry nectar, and found a tendency to increase the antioxidant capacity of approximately $9 \%$ at both ambient $\left(16 \pm 3{ }^{\circ} \mathrm{C}\right)$ and refrigeration $\left(4 \pm 2{ }^{\circ} \mathrm{C}\right)$ temperatures. Valdés et al. ${ }^{[38]}$ evaluated guava juice packed in glass packages, and found a $30 \%$ inhibition of DPPH radical, which is lower than this study, once the lowest percentage was approximately $33 \%$ inhibition at the end of storage period for the formulation containing pectinase and rice flour (T8).

Figure $3 \mathrm{E}$ shows phase separation of guava nectars. The sedimentation occurred more rapidly at the beginning of the process, specifically in the first two weeks of storage, followed by a gradual increase in the height of the precipitate until a stable point was reached. No significant difference was observed for the sample containing xanthan gum (T2) when compared to the control. All the other formulations showed greater stability when compared to the control, especially the formulations containing pectinase (T5, T6, T7, T8), which reached $88 \%, 80 \%, 91 \%$ and $75 \%$ of stabilization, respectively at the end of the storage.

Among the samples containing only gum, the sample with rice flour (T4) showed high stability, demonstrating that the xanthan concentrations used in the present study did not play an important role in stabilizing guava nectars. Godoy ${ }^{[15]}$, studied the stability of guava nectar during 180 days of storage, and found $99 \%$ stability using $0.175 \%$ xanthan, which was greater than the amount used in this study. Garruti ${ }^{[48]}$, used $0.2 \%$ xanthan gum in passion fruit juice, and found $100 \%$ stability for 180 days, while Souza ${ }^{[16]}$ stood out that the addition of $0.2 \%$ xanthan gum was one of the best treatments to stabilize peach nectar (94.7\%). The fact of xanthan gum did not produce good results in terms of stabilizing the guava nectars of this study does not corroborate the studies in literature. Vendrúscolo ${ }^{[49]}$ reported that the enzymatic treatment of carambola pulp decreased sedimentation by about $62 \%$ when compared to the untreated pulp, probably due to pectin solubilization and release the intercellular juice.

\section{Conclusion}

The quality and physicochemical composition of nectars was affected by the addition of hydrocolloids and/or enzymes, and the addition of enzyme pectinase led to a greater extraction of soluble solids and carotenoids, as well as improved stabilization during phase separation ( $75 \%$ to $91 \%$ ), especially for the formulation containing pectinase and guar gum. The nectars containing gums, in turn, exhibited higher stability of phenolic compounds and L-ascorbic acid, which directly influenced the higher antioxidant capacity when compared to the formulations containing pectinases, highlighting the formulation with xanthan gum. According to our results, we conclude that the production of nectar on an industrial scale is a promising alternative, and the use of gums or enzymes can increase carotenoids content and confer protection to phenolic compounds and L-ascorbic acid.

\section{Acknowledgements}

The authors would like to thank CNPq (Conselho Nacional de Desenvolvimento Científico e Tecnológico) for funding and support.

\section{References}

1. Joseph, B., \& Mini Priya, R. (2011). Review on nutritional, medicinal and pharmacological properties of guava (Psidium guajava L). International Journal of Pharma and Bio Sciences, 2(1), 53-69.

2. Azzolini, M., Jacomino, A. P., \& Bron, I. U. (2004). Índices para avaliar qualidade pós-colheita de goiabas em diferentes estágios de maturação. Pesquisa Agropecuária Brasileira, 39(2), 139-145. http://dx.doi.org/10.1590/S0100-204X2004000200006.

3. Nascimento, R. J. (2010). Potencial antioxidante de resíduo agroindustrial de goiaba (Dissertação de mestrado). Universidade Federal Rural de Pernambuco, Recife.

4. Associação Brasileira das Indústrias de Refrigerantes e de Bebidas não Alcoólicas - ABIR. (2011). O setor. Retrieved in 2015, December 7, from http://abir.org.br/categoria/o-setor/.

5. Instrução Normativa $n^{\circ} 12$, de 4 de setembro de 2003. (2003). Padrões de Identidade e Qualidade para Sucos e Néctares. Diário Oficial da República Federativa do Brasil, Brasília, DF. Retrieved in 2015 October 16, from http://extranet.agricultura. gov.br/sislegis

6. Mollov, P., \& Maltschev, E. (1996). Physico-chemical characteristics of orange juice cloud. Journal of Food Science and Food Agriculture, 21, 250-253. http://dx.doi.org/10.1002/ jsfa.2740210508.

7. Dickson, E. (2003). Hydrocolloids at interfaces and the influence on the properties of dispersed systems. Food Hydrocolloids, 17(1), 25-39. http://dx.doi.org/10.1016/S0268-005X(01)00120-5.

8. Sousa, M. A. C., Yuyama, L. K. O., Aguiar, J. P. L., \& Pantoja, 1. (2006). Suco de açaí (Euterpe oleracea Mart.): avaliação microbiológica, tratamento térmico e vida de prateleira. Acta Amazonica, 36(4), 483-496. http://dx.doi.org/10.1590/S004459672006000400010.

9. Rodrigues, R. D. P. (2013). Obtenção de néctar de banana por maceração enzimática de polpa da variedade prata-anã. (Dissertação de mestrado). Universidade Federal do Ceará, Fortaleza.

10. Instituto Adolfo Lutz - IAL. (2008). Normas Analíticas do Instituto Adolfo Lutz: métodos químicos e fisicos para análise de alimentos. 4. ed. São Paulo: IAL.

11. Swain, T., \& Hillis, W. E. (1959). The phenolic constituents of Prunus domestica L.- the quantitative analysis of phenolic constituents. Journal of the Science of Food and Agriculture, 10(1), 63-68. http://dx.doi.org/10.1002/jsfa.2740100110.

12. Association of Official Analytical Chemists-AOAC. (1995). Official methods of analysis. 16th ed. Washington: AOAC. $1141 \mathrm{p}$.

13. Brand-Willians, W., Cuvelier, M. E., \& Berset, C. (1995). Use of a free radical method to evaluate antioxidant activity. Food Science and Technology, 28, 25-30. http://dx.doi.org/10.1016/ S0023-6438(95)80008-5. 
14. Zambiazi, R. C. (2010). Análise fisico-química de alimentos. Pelotas: Universitária. 202 p.

15. Godoy, R. B. (1997). Gomas na estabilidade do néctar e do suco de goiaba (Psidium guayava L.). (Dissertação de mestrado). Universidade Federal de Pelotas, Pelotas.

16. Souza, J. L. L. (2009). Hidrocolóides nas características fisicoquímicas e sensoriais do néctar de pêssego (Prunus pérsica L. Batsch). (Dissertação de mestrado). Universidade Federal de Pelotas, Pelotas.

17. Silva, D. S., Maia, G. A., Sousa, P. H. M., Figueiredo, R. W., Costa, J. M. C., \& Fonseca, A. V. V. (2010). Estabilidade de componentes bioativos do suco tropical de goiaba não adoçado obtido pelos processos de enchimento a quente e asséptico. Ciência e Tecnologia de Alimentos. 30(1), 237-243. http:// dx.doi.org/10.1590/S0101-20612010000100035.

18. Mattietto, R. A., Lopes, A. S., \& Menezes, H. C. (2007). Estabilidade do néctar misto de cajá e umbu. Ciência e Tecnologia de Alimentos. 27(3), 456-463.

19. Leitão,A. M. (2007). Estabilidade fisico-química, microbiológica e sensorial de néctar de amora-preta (Rubus spp.), Cv. Tupy, embalado em polipropileno, no armazenamento (Dissertação de mestrado). Universidade Federal de Pelotas, Pelotas.

20. Carvalho, J. M., Maia, G. A., Figueiredo, R. W., Brito, E. S., \& Rodrigues, S. (2007). Development of a blended nonalcoholic beverage composed of coconutwater and cashew apple juice containing caffeine. Journal of Food Quality, 30(5), 664-681. http://dx.doi.org/10.1111/j.1745-4557.2007.00149.x.

21. Silva, A. P. V., Maia, G. A. O., Oliveira, G. F. S. O., Figueiredo, R. W., \& Brasil, I. M. (1999). Estudo da produção do suco clarificado de cajá (Spondias tuberosa L.). Ciência e Tecnologia de Alimentos., 19(1), 33-36. http://dx.doi.org/10.1590/S010120611999000100009.

22. Essa, H. A. A. (2002). Effect of pectinase enzyme treatment on the the rheological, physical and chemical properties of plum, banana and guava juices. Polish Journal of Food and Nutrition Sciences. 11-52(3), 13-19.

23. Byaruagaba-Bazirake, G. W., Van Ransburg, P., \& Kyamuhangire, W. (2012). Characteristics of enzyme-treated banana juice from three cultivars of tropical and subtropical Africa. African Journal of Food Science and Technology., 3, 277-290.

24. Demir, N., Acar, J., \& Bahceci, K. S. (2004). Effects of storage on quality of carrot juices produced with lactofermentation and acidification. European Food Research and Technology, 218, 465-468. http://dx.doi.org/10.1007/s00217-004-0883-8.

25. Vandresen, S. (2007). Caracterização físico-química e comportamento reológico de sucos de cenoura e laranja e suas misturas (Dissertação de mestrado). Universidade Federal de Santa Catarina, Florianópolis.

26. Pinheiro, A. M. (2008). Desenvolvimento de néctares mistos à base de caju (Anacardium occidentale L) e açaí (Euterpe oleracea mart.). (Dissertação de mestrado). Universidade Federal do Ceará, Fortaleza.

27. Corrêa, M. I. C. (2002). Processamento de néctar de goiaba (Psidium guajava L. var. Paluma): compostos voláteis, características físicas e químicas e qualidade sensorial (Dissertação de mestrado). Universidade Federal de Viçosa, Viçosa.

28. Beisman, R. B. (2000). Processamento e avaliação da qualidade do néctar e néctar light de dois cultivares de pêssego adaptados ao clima subtropical (Dissertação de mestrado). Escola Superior de Agricultura “Luiz de Queiroz", Universidade de São Paulo, Piracicaba.

29. Sreenath, H. K., Sudarshanakrishana, K. R., \& Santhanam, K. (1994). Improvement of juice recovery from pineapple pulp/residue using celulases and pectinases. Journal of
Fermentation and Bioengineering, 78(6), 486-488. http:// dx.doi.org/10.1016/0922-338X(94)90054-X.

30. Brasil, I. M., Maia, G. A., \& Figueiredo, R. W. (1995). Physical-chemical changes during extraction and clarifi cation of guava juice. Food Chemistry, 54(4), 383-386. http://dx.doi. org/10.1016/0308-8146(95)00066-R.

31. Nisida, A. L. A. C., Menezes, H. C., \& Tocchini, R. P. (2002). Estabilidade de suco de laranja (Citrus Sinensis) refrigerado, acondicionado em embalagem asséptica. Brazilian Journal of Food Technology, 5, 95-100.

32. Sharon, E. S., Dantas, S. T., Menezes, H. C., Soares, B. M. C., \& Nunes, M. F. (2007). Estabilidade sensorial de suco de maracujá pronto para beber acondicionado em latas de aço. Ciência e Tecnologia de Alimentos., 27(4), 772-778. http:// dx.doi.org/10.1590/S0101-20612007000400016.

33. Tribst, A. A. L. (2008). Efeito do processamento por alta pressão dinâmica combinado com tratamento térmico brando na inativação de Aspergillus niger em néctar de manga (Dissertação de mestrado). Universidade Estadual de Campinas, Campinas.

34. Arruda, A. F. (2003). Estudo da estabilidade do néctar de manga (Mandifera indica L.) envasado em garrafa PET, comparado com envasados em embalagem cartonada e lata de alumínio (Dissertação de mestrado). Universidade Estadual de Campinas, Campinas.

35. Lin, C. H., \& Chen, B. H. (2005). Stability of carotenoids in tomato juice during storage. Food Chemistry, 90(4), 837-846. http://dx.doi.org/10.1016/j.foodchem.2004.05.031.

36. Fernandes, A. G., Maia, G. A., Sousa, P. H. M.., Costa, J. M. C., Figueiredo, R. W., \& Prado, G. M. (2007). Comparação dos teores em vitamina $\mathrm{C}$, carotenóides totais e fenólicos totais do suco tropical de goiaba nas diferentes etapas de produção e influencia da armazenagem. Alimentos e Nutrição., 18, 431438.

37. Paludo, M. C., \& Krüger, R. L. (2011). Ação da enzima pectinase na extração do suco de jabuticaba. Arquivos de Ciência da Saúde UNIPAR., 15, 279-286.

38. Valdés, S. T., Vaz Tostes, M. G., Della Lucia, C. M., Hamacek, F. R., \& Pinheiro-Sant'ana, H. M. (2012). Ácido ascórbico, carotenoides, fenólicos totais e atividade antioxidante em sucos industrializados e comercializados em diferentes embalagens. Revista do Instituto Adolfo Lutz, 71(4), 662-669.

39. Singh, S. P., \& Pal, R. K. (2008). Controlled atmosphere storage of guava (Psidium guajava L.) fruit. Postharvest Biology and Technology, 47(3), 296-306. http://dx.doi.org/10.1016/j. postharvbio.2007.08.009.

40. Quinteros, E. T. T. (1995). Processamento e estabilidade de néctar de acerola-cenoura (Dissertação de mestrado). Universidade Estadual de Campinas, Campinas.

41. Brito, I. P., Faro, Z. P., \& Melo, S. C., Fo. (2004). Néctar de maracujá elaborado com água de coco seco (Cocos nucifera, L.). In Congresso Brasileiro de Ciência e Tecnologia de Alimentos (p. 9). Recife: Sociedade Brasileira de Ciência e Tecnologia de Alimentos.

42. Oliva, P. B., Menezes, H. C., \& Ferreira, V. L. P. (1996). Estudo da estabilidade do néctar de acerola. Ciência e Tecnologia de Alimentos., 16, 228-232.

43. Carvalho, J. M., Maia, G. A., Figueiredo, R. W., Brito, E. S., \& Garruti, D. S. (2005). Bebida mista com propriedade estimulante à base de água de coco e suco de caju clarificado. Ciência e Tecnologia de Alimentos., 25(4), 813-818. http:// dx.doi.org/10.1590/S0101-20612005000400030.

44. Fellows, P. (1997). Food processing technology: principles and practice. Abington: Woodhead. $505 \mathrm{p}$.

45. Burdurlu, H. S., Koca, N., \& Karadeniz, F. (2006). Degradation of vitamin $\mathrm{C}$ in citrus juice concentrates during storage. 
Journal of Food Engineering, 74(2), 211-216. http://dx.doi. org/10.1016/j.jfoodeng.2005.03.026.

46. Correa-Neto, R. S., \& Faria, J. A. F. (1999). Fatores que influem na qualidade do suco de laranja. Ciência e Tecnologia de Alimentos., 19(1), 153-160. http://dx.doi.org/10.1590/ S0101-20611999000100028.

47. Resolução RDC n 269, de 22 de setembro de 2005. (2005, 23 de setembro). Aprova o regulamento técnico sobre a Ingestão Diária Recomendada (IDR) de proteína, vitaminas e minerais. Diário Oficial da República Federativa do Brasil, Brasília.
48. Garruti, D. S. (1989). Contribuição ao estudo da estabilização física do suco de maracujá integral (Passiflora edulis F. flavicarpa Deg) (Tese de doutorado). Universidade Estadual de Campinas, Campinas.

49. Vendrúscolo, A. T. (2005). Comportamento reológico e estabilidade fisica de polpa de carambola (Averrhoa carambola L.) (Dissertação de mestrado). Universidade Federal de Santa Catarina, Florianópolis.

Received: May 20, 2016

Revised: Mar. 15, 2017

Accepted: May 12, 2017 